\title{
Prospective use of ecological tourism in Ukraine and integrative view of international experience
}

\author{
O. V. Ulyanchenko ${ }^{1}$, O. V. Borysova ${ }^{1}$, 0. O. Akhmedova' ${ }^{2}$, S. I. Sysoieva', \\ R. M. Sheludko' ${ }^{1}$ S. V. Stankevych ${ }^{1 *}$, T. V. Kovalova ${ }^{3}$, B. D. Khalmuradov ${ }^{4}$ \\ Yu. Ye. Kharlamova ${ }^{5}$
}

\author{
1V.V. Dokuchaev Kharkiv National Agrarian University \\ v. Dokuchaevske, Kharkiv region, 62483, Ukraine \\ 2S. Kuznets Kharkiv National University of Economics \\ 9A Nauky Avenu, Kharkiv, 61166, Ukraine \\ ${ }^{3}$ Kharkov National Automobile and Highway University \\ 25 Yaroslava Mudrogo St., Kharkiv, 61002, Ukraine \\ ¿National Aviation University \\ 1 Komarova Av., Kyiv, 03058, Ukraine \\ 5National University of Civil Defense of Ukraine \\ 94 Chernusevska St., Kharkiv 61023, Ukraine \\ E-mail: sergejstankevich1986@gmail.com
}

Received: 13.12.2019. Accepted 20.01.2020

\begin{abstract}
The international experience of the rural green (ecological) tourism objects development has been analysed in the article; the distinctive features and types of rural tourism have been outlined; both the peculiarities of definitions of this type of tourism in different countries of the world and the features of its organization have been studied; the real examples of ecological (rural green) tourism development in different countries and features of its organization have been presented. It has been demonstrated that in some countries more active forms of green (rural green) tourism are developing, in particular, cycling, horseback riding in scenic rural areas, fishing, etc.; in others, this type of tourism is primarily a family holiday in the countryside, an opportunity to get acquainted with national cuisine, winemaking, etc., to get to know national culture and customs, to visit interesting natural and cultural monuments. It has been also noted that international experience of the ecological tourism (rural green tourism) organization includes various forms and methods, demonstrates its growing popularity among holidaymakers, significant potential in the development of rural regions of the country, constantly increasing profitability. The ways of international experience usage of the ecological tourism (rural green tourism) organization in Ukraine nowadays has been also indicated in the article; it has been stated that the type of tourism researched in the article is a mature, dynamically developing tourism direction, and accordingly, it has already accumulated valuable experience necessary for the development of this type of tourism in Ukraine, which has huge potential for the development of its own ecological (rural green) tourism.
\end{abstract}

Keywords: Rural green tourism; Agrotourism; Eco-tourism; Farm tourism; Hotels; Classification; Farmsteads; Hospitality industry; Tourism business

\section{Introduction}

Now-a-days, tourism as a type of business activity is a unique economic, social, legal and cultural-communicative phenomenon. The Charter of Tourism, adopted by the World Tourism Organization (WTO) in 1985, states that everyone has the right for rest and leisure, including the right for a reasonable restriction on working hours and periodic paid leave, as well as the right to move freely without restrictions. Such kind of tourism, as rural green tourism as a mass phenomenon, became especially developed in the second half of XX century. The rapid pace of life, urbanization, the development of high technologies and communications have created conditions for the formation and development of rural green tourism in different countries of the world. The people's desire to take a break from urban noise, tank energy and change their lifestyles creates an extraordinary level of demand for rural green tourism services. In this regard, there is a growing scientific interest in this type of tourism, and research in this field is becoming more relevant and topical. Many foreign scientists have devoted their researches to the rural green (ecological) tourism development in their countries and internationally. Among them the works of H. Caravelli, T. Ducha, M. Clark, V. V. Havoretsky, M. Lonch and of such Russian researchers as A. A. Alexandrova, S. N. Kaznacheyeva, S. O. Chelnokova, E. A. Korovina, Y. V. Pecherytsia, M.I. Shevchenko and others take a special place. These scholars' views on the content of the rural green tourism concept as a form of tourism have certain methodological importance, since a form, as a cognitive category, is the embodiment of a particular content. Thus, in these works, rural green tourism is considered as a form that reflects the internal and external side of this type of economic activity, indicates the way of its implementation on a special basis inherent to one or another country using certain resources that this country possesses. Ukrainian scientists V. Vasyliev, V. Zaitseva, N. Kudla, L. Psheburska, P. Stoliarchuk, O. Chopik, K. Yatsenko and others have also researched the problem and developed it in a number of their works. 
In general, the scientists admit that in each country, this type of tourism has its own goals, quite specific functions aimed at the economic and social development of rural areas, helps tourists perceive the authenticity and beauty of nature. In many countries, it is one of the leading directions in tourism that is reflected in the national concepts of tourism development; it is aimed at solving a number of socio-cultural tasks: preservation of national traditions and socio-cultural heritage, natural, historical and cultural environment, architectural and historical space, revival and promotion of traditional values and way of life. From our point of view, this is in line with the growing general objective trend, which presents a definite opposition to the global process of globalization the growing tourists' interest in the pristine nature and traditional culture with its ethnographic specificity. Therefore, the greater the pressure of civilization to achieve unification and to blur national and cultural boundaries, the greater is the peoples' attraction to their traditional ethno cultural sources. Nowadays it is embodied in the growing interest in nature and rural life, in the desire to relax in an environment that provides psychological discharge for a person tired of the modern realities of urban human life.

\section{Research Methodology}

The research, the main results of which are presented in the article, is based on the fundamental provisions of contemporary economics, including the theory of entrepreneurship, institutionalism, basic principles of the economic organization theory, the property rights theory, more specifically - concerning the use of a common resource, etc. The methodological basis of the article is the dialectical method and systematic approach to the analysis of the international experience of the ecological (rural green) tourism objects formation as a phenomenon of not only organizing leisure time for travellers, but also an entrepreneurial activity of rural population, and its implementation in Ukraine. The method of scientific abstraction clarifies the basic definitions of agrotourism, ecotourism, rural green tourism, which are not identified in foreign practice, but in the scientific literature these definitions are recognized as equal and their certain identification is allowed; the classification of "Bed \& Breakfast" as accommodation place has been identified and highlighted. The specific forms of this type of tourism in different countries have been studied with the methods of deduction and induction, analysis and synthesis; the characteristics of different types of ecological (rural green) tourism development as a phenomenon of rural population's entrepreneurship in different countries and regions of these countries have been generalized; it has been considered what aspects of the international experience of ecotourism (rural green tourism) are already being used in Ukraine, and which should be addressed. An abstract-logical method has been used to summarize and formulate conclusions. The information basis of the article are special scientific, reference and partially non-fiction literature, information resources of the World Wide Web, data of foreign and domestic public organizations, including the World Tourism Organization (UNWTO), World Wide Fund for Nature, Unions promoting tourism development; materials of the Kharkiv Regional Council promoting the ecological (rural green) tourism development and supporting the development of agro-farmsteads, etc.

\section{Results}

The tourism industry around the world is now experiencing a time of active development. Therefore, along with the traditional (active and mass) forms of recreation, the so-called "green traveling" is getting popular, that is, instead of resting according to the "three S" formula (sun - sea - sand), the "three L" formula (landscape - lore - leisure) is being proposed. The ideas of life ecologization are increasingly affecting the tourism industry (Balandin, 2012). "Green traveling" is embodied in one of the most popular types of tourism in the world - green rural tourism or agrotourism (farm tourism) (Klikunova, 2008). The concepts of "ecological tourism", "rural tourism" and "agrotourism" are not identical in foreign practice (Table 1). However, despite the fact that in different countries various terms are used to indicate rural tourism and each type of tourism has its own specificities, sets particular goals aimed at meeting the travellers' specific needs and has different forms of organization, the essence is approximately the same. Thus, some scholars propose to consider all concepts: ecological tourism, rural green tourism, agrotourism, farm tourism, natural tourism as equal (Pecheritsa \& Shevchenko, 2012). They also accept their certain synonymy.

Table 1. Basic definitions of ecotourism that express its essence (according to Grigoryeva, 2008).

\section{Type of tourism}

Ecological tourism

Soft tourism

Rural tourism

Farm tourism

\section{Definitions}

It is an environmentally friendly traveling to the places of relatively pristine nature for the sake of relaxation and acquaintance with the natural, historical and cultural features of the area. It contributes to the nature protection and creates economic conditions under which the protection of natural resources becomes advantageous to the local population.

While the main goal of "hard tourism" is to maximize profits, soft tourism aims not only to succeed in business, but also to care for the well-being of the tourist regions, careful use and replenishment of their resources, minimizing the damage caused to the environment.

The object of rural tourism is rural territories. It provides the development of the tourist routes, recreational sites, agricultural, folk museums, and tourist service centres that offer the help of tourist guides.

These trips are connected with the agricultural sector. This tourism is manifested in many forms, but always includes rented accommodation, which has two basic forms: 1) leased premises with the service within the farmstead; 2) night self-service accommodation on the territory belonging to the farmstead.

The concepts of both green and rural green tourism as well as agrotourism can vary greatly from country to country, depending on the approach used by some professionals in this type of tourism activity (Table 2). 
Table 2. Features of rural green and agrotourism definitions in foreign countries (according to Diatov, 2011; Pecheritsa \& Shevchenko, 2012; Selskiy, 2019).

\section{Country}

The USA

Great Britain

India

Cyprus

Germany

Switzerland

Poland

\section{Definition}

Green tourism is an essential respite in the countryside, where tourists lead a rural lifestyle during some period, get acquainted with the local culture, folk crafts, participate in rural work on farms. The most common forms are relaxation on the ranch, horseback riding.

Rural tourism is a holiday in a rural countryside that offers both economy and luxury accommodation in the remodelled old farmsteads or specially built mini-hotels and traditionalstyle houses. In great demand is the type of rural tourism that combines tourism with the work on the organic farms (Worldwide Opportunities on Organic Farms - WWOOF).

Rural green tourism is any type of tourism that shows tourists the rural life of the country, the arts, culture and ethno-cultural heritage in the countryside, which brings economic and social benefits to the local community, ensures interaction between tourists and local residents.

Rural tourism is a type of tourism activity that ensures close contact with the local culture by incorporating unique elements of the landscape, historic and architectural sites, crafts and cuisine into the tourist product.

Rural (soft) tourism is a segment of the tourism market that is distinguished by the recreational activities in nature, in the attractive rural areas, in the natural conservation areas. Its varieties are scientific tourism, wildlife watching and photography, fishing and hunting, sports, adventure tours.

Rural tourism is a respite on the farms, in the country houses, rural hotels, and old castles, reconstructed as high-end hotels with a full range of leisure services.

Rural tourism is the use of the agricultural sector resources to meet the tourists' needs. The term "eco-village" is used as a socially oriented territory providing recreation in the natural environment utilising traditional accommodation and food.

To develop the hospitality industry the World Tourism Organization (UNWTO), which has been operating in the world since 1925, developed a standard classification of tourist accommodation facilities, according to which the accommodation facilities are divided into collective and individual. In different countries, different symbols are used to indicate accommodation categories. In particular, in Iceland the rural dwellings are categorized as rooms of three categories and guesthouses of A, B, C, D, E, F, G categories; in the countries of Southern Europe the categorization of farmsteads from one to five stars is in force (Spilka, 2019a). The concept of "Bed \& Breakfast" is common in the USA and the UK. At the beginning of the XXI century, the rural tourism industry is recognized by UNWTO experts as a significant, fastest growing sector of the global tourism business. The volume of tourist services in the field of rural tourism in post-industrial countries is now almost $2-4$ times higher than the growth of the hotels and resort service in these countries. At the present stage, all national rural tourism organizations in Europe have joined the European Federation for Farm and Village Tourism, abbreviated as EuroGites. The main goals of this organization are to promote the development of rural green tourism and to invest in rural tourism development projects (Rozvitok, 2019). Moreover, this is a very important process, because the fact of the international organizations creation uniting national level organizations indicates the highest level reached by this type of tourism activity. The features of rural green tourism organization in different countries are presented in Table 3.

The European Union sees rural tourism as a major lever for the economic recovery of its rural territories. According to the experts of the European Bank for Reconstruction and Development, it is 20 times more expensive for the residents from the rural territories to settle down in a city than to create the conditions for their life and work in the countryside. It has been also estimated that the income from one bed is equivalent to the farmer's annual income from one cow (Yatsenko, 2019).

In compliance with the international categorization of the agro-recreational service and in accordance with the concept of "Bed \& Breakfast" the following separate categories of lodging establishments are also attached to rural green tourism: B\&B cottage; B\&B farm vacation; B\&B homestay; B\&B farmstay (Oppeld \&, Gordiyan, 2014).

According to the accepted classification, the characteristics of temporary accommodations that belong to the "Bed \& Breakfast" type are presented in Table 4. Classic European traditions and values of rural holidays are professed by the United Kingdom. The system of regional tourism organization was created here in 1969 with the adoption of the Law on Tourism Development. English tourism is all-season; it is very popular among the British to spend not only summer holidays in the countryside but also to celebrate Christmas there. Within the "Bed \& Breakfast" system, accommodation in the country houses and mini-hotels located in the countryside stand aside as a separate type of the B\&B (Stolyarchuk \& Dominyuk, 2010). In this country, the National Organization of Rural Tourism and Agrotourism provides accreditation of residences. English farmers have teamed up to promote the variety of services they are willing to provide in their homes. In particular, old farms are now being restored in south-west England, which is very attractive to tourists, where higher level of comfort is combined with the partially preserved old furniture (Zaytseva, 2014).

Europe, France and Spain are the leaders in terms of the rural tourism industry development. Here, rural tourism has become a highly profitable sector of their international economic specialization long before.

France's rural tourism is represented by the National organization of holiday homes and green tourism, which offers agro-villages for every taste and type of holiday. Agro-settlements are certified to the highest national service standards. It is worth noting that in France, the farmstead is not necessarily the possession of farmers. In fact, only every third farmer owns such a farm. Other owners are city dwellers and travel companies. 
Table 3. Features of the rural green tourism organization in different countries (according to Spilka, 2019; Rozvitok, 2019; Yatsenko, 2019.

\section{Country \\ Features of the rural green tourism organization}

Italy Agrotourism business is closely linked to the resort tourism; international specialization: gastronomic and tasting tourism.

Austria Participation of tourists in picking herbs, preparing dairy products, pasturing livestock; active mountain and ecological tourism.

Finland Houses without hosts located on the picturesque banks of lakes and rivers.

Romania National Association of Rural and Cultural Tourism was established and is operating; specialization: ethnographic and gastronomic tourism.

Hungary The tax benefits are stipulated for rural tourism, equestrian tourism is an international specialization.

Poland There are no tight connections with the country's traditions; tourists are offered only accommodation and meals.

France Seaside agro-farmsteads, horse farms, wine agro-farmsteads, ski chalets, agro-cottages, castles, fishing houses.

Spain Rural hotels are open in the Canary and Balearic Islands, as well as in converted monasteries and historic castles.

Denmark The National Agrotourism Association was established and is operating; specialization is bicycle touring.

Iceland Categorization of hotel rooms into three categories, categorization of guest houses $(A, B, C, D, T, F, G)$.

Germany The majority of tourists arrive to participate in international fairs and trade shows.

United Rural tourism is characterized by affordable prices, special discounts for children, printed advertising and information Kingdom catalogues of rural green tourism.

Table 4. Classification of "Bed \& Breakfast" accommodation (according to Stolyarchuk \& Dominyuk, 2010; Yevropejskij, 2013; Oppeld \&, Gordiyan, 2014).

Title

Bed \& Breakfast cottage

Bed \& Breakfast farm vacation

Bed \& Breakfast homestay

Bed \& Breakfast farmstay
General characteristics

Rental cottage in a resort and recreation area, on the territory with the rural status or which belongs to the resort

Family vacation with children in a picturesque countryside with valuable recreational resources

Living in the owner's farmhouse with his family in separate guest rooms

Living in the farmer's house or in the camping on the territory of the farm
Duration of stay

$6-7$ days

Seasonal accommodation during holidays

\section{Feature}

Accommodation at the seaside, lake or in the mountains

Possibility for children of different ages to interact with peers and relax in a "home" atmosphere apart from parents

Acquaintance with the traditions, culture, lifestyle of the family with which the tourists live

Eating and purchasing of products grown and manufactured by the owner of the farmstead, participation in the farm work

Along with the farmstead vacations, the holidays in the so-called "resort settlements" located in the places with beautiful scenic nature and on the territories of the landscape parks become more and more popular. They consist of 3 to 25 wooden chalets for 4-6 guests each. To promote the development of resorts in France, a special investment program for the development of their infrastructure - "Gotes de France program, chalets-loisirs" is in operation. Besides, attention should be paid to the "panda hotels" network that was certified by the World Wide Fund for Nature (WWF) and meets the following requirements: 1) has a moderate level of service that does not require significant costs; 2) complies with the terms of environmental protection; 3) offers tourists the 
fauna reference books, ecotourism brochures, etc. (World, 2019). Rural green tourism is now closely intertwined with ecotourism, moreover, partially, these concepts are combined. The farmsteads of this type are mainly located in the national reserves of France (Agroturizm, 2019a). In general, rural green tourism in France is an important indicator of the economic well-being of the population and a source of income to the country's budget. Italy draws tourists' attention to the historical traditions of rural holidays in the mountains and foothills of the Alps, the Apennines and along the coastline. Rural tourism in Italy is the main form of entrepreneurial employment for the rural population. Therefore, in this country, the agrotourism business is closely intertwined with the resort tourism (Italiya, 2019). An important factor of Italy's international agricultural specialization is wine and gastronomic tourism. Although rural recreation services in Italy are almost twice as expensive as in Spain or France, it is very popular with both foreigners and Italians, who also enjoy traveling around their country. Thanks to the preferential tax regime, a network of the prestigious holiday cottages and guesthouses, not less than 3-star levels, has been developed here and the guesthouses are equipped with all the necessary recreational infrastructure (from a jacuzzi and a swimming pool to the tennis courts and the horse riding arenas). Each country province is famous for its varieties of grapes and wines, which can be tasted at small private wineries and home-based distilleries. The owners of the agro-cottages offer to their guests wine, cheese or meat cellars, provided that the free use of this food is included into the tourists' cost of accommodation (Yatsenko, 2019).

Spain's rural green tourism is called Turismo Rural. Its infrastructure includes about 10,000 institutions. Among them are small and large hotels, both quite modest and very comfortable. Tourists are provided not only with food and accommodation, but also with the services such as exploring local traditions and folklore, sightseeing, hiking of varying difficulty with a tourist guide, horse and donkey riding, mushroom picking, hunting and fishing. One can also get acquainted with the agricultural production (growing fruits and vegetables, animal husbandry), mastery of winemaking, cheese and sausage production, participation in tastings, visiting workshops, etc. (Selskiy, 2019b).

In Spain, there is also a division of accommodation located in the rural areas, which are defined as entities of agrotourism and are subject to taxation. They include the following classes: 1) HR (hotel rural) - a rural hotel; 2) CA (castillo) - a castle, historical estate; 3) CR (casa rural) - a rural house.

The most common form of rural tourism in Spain is the rural "finca" hotel. It is a rural house or even a farm that offers its services to tourists. "Casa rural" is another type of residence in Spain. It is a simple rural house, part of which is offered to tourists only during the summer period and it is the main difference from finca (Selskiy, 2019b). Casa rural is the perfect way to see Spanish life from the inside out, as tourists live with their rural family and daily watch the rhythm and lifestyle of the village.

In total, there are more than 5,000 rural holiday destinations in Spain with a total number of 27,000 beds. The 750 rural hotels are categorized in accordance with "Inns of Spain" system and receive 1 - 4 symbolic tulips. Some hotels operate on the basis of monasteries, historical castles (Agroturizm, 2019b). The Agrotourism Association of Spain has complete and accessible information on rural estates and their characteristics on the official site, which is actively used by employees of agrotourism firms (Do gumannogo, 2019).

Germany is actively developing its green tourism. Many one-day guests from Eastern Europe, especially from neighbouring Poland, visit this country and do shopping tours. In Germany, the concept of tourism development in the peripheral regions has been developed in order to spread cheap tourism in the tourism market without using expensive infrastructure and providing comfortable living conditions. The development of rural green tourism in Austria now has 15,000 registered agrotourism farms with a total capacity of 170,000 beds (Yevropejskij, 2013).

It is worth studying the experience of Ukraine's European neighbours: Hungary, Romania, Poland. Hungary's environmental or rural green tourism legislation supports the sphere of private agricultural farming, where appropriate preferential tax instruments are formed. The most popular areas include the south-western region of Vash, the eastern region of Solnok and the notorious Hortobad steppe. The "highlight" of rural tourism in this country is its combination with national horse-riding traditions. In Romania, the National Association of Rural, Environmental and Cultural Tourism represent the interests of owners of agro-farmsteads. In this country, rural tourism first and foremost is developing in the Southern Carpathians and focuses on the same advantages as in Ukraine, i.e. on preserving natural environment and national and cultural traditions (Yevropejskij, 2013).

Polish legislation distinguishes the basic concepts and principles of ecological (rural green) tourism from other types of tourism services provided in rural areas, but which are legally related to the entrepreneurial activities. In rural tourism, Polish government sees a source of development for regions that have natural resources to build economic industries. The agrotourism product offered by Polish farms is partly reduced only to overnight accommodation and catering, but it is understood that the profitability of overnight accommodation facilities increases with the provision of other related services (Yatsenko, 2019).

In Ukraine, based on the Polish experience, works the system of ecological certification and voluntary categorization "Green farmstead" developed by the All-Ukrainian Union for the promotion of rural green tourism. The certification scheme is based on the principles of reducing the adverse impact of agrotourism objects on the environment, support of the folk traditions and crafts, support of the local economy, development of the environmentally friendly types of entertainment and recreation (Spilka, 2019b). In Ukraine, following the example of foreign categorizations, the national categorization system is already being developed - the Ukrainian Hospitality Farmstead sign is issued by the Union for the Promotion of Rural Green Tourism in Ukraine and can be used as a marketing tool for increasing the farmstead's popularity. In particular, a regional network of "Welcoming farmsteads of Kharkiv Region" in the number of 37 farmsteads of different categories were created in the Kharkiv region for the first time, and they were included in the all-Ukrainian network "Ukrainian welcoming farmsteads". Two of them were categorized earlier in 2014 (Na Harkivshchini, 2019).

\section{Conclusion}

Thus, the international experience of the ecological tourism (rural green tourism) development includes various forms and methods, demonstrates its growing popularity among holidaymakers, considerable potential in the development of rural regions of the country, constantly increasing profitability. In many countries of the world, one or another vector of the ecological tourism (rural green tourism) development has already been identified. Italy, Spain, France are visited by those who want to rent a house in the countryside and get acquainted with the famous cuisine and winemaking in these countries. The regions of Tuscany, Bordeaux, Andalusia have thousands of agro-settlements. Other countries practice more active types of tourism - fishing, cycling, horseback riding etc. Ecological tourism as a rural green tourism in Poland, Germany, Hungary and some other countries is an opportunity to learn more about culture and customs, and to live close to natural and cultural attractions. 
In many countries, ecological tourism is a fairly mature tourism direction, which has already overcome certain stages of its development, and accordingly has accumulated valuable experience, which is really important for the development of this type of tourism in Ukraine, which has huge potential for the development of its own ecological (rural green) tourism.

\section{References}

Agroturizm v Ispanii. (2019b). Available from: https://www.datscha-booking.com/173/agrotourismo/agro-spain.html (in Ukrianian) Agroturizm vo Francii. (2019a). Available from: https://www.datscha-booking.com/173/agrotourismo/france-agro.html. (In Russian). Balandin, Yu. (2012). Na derevnyu k dedushke. Osen'yu sel'skij turizm perezhivaet pik populyarnosti. Rossijskaya Biznes-gazeta, 2012. 25 sentyabrya, 865 (36) (in Russian).

Daitov, V.V. (2011). Mirovoj opyt organizacii agroturizma v kontekste razvitiya sel'skih regionov Rossii. Proceed. III Int. Sc. Conf. "Eko- i agroturizm: perspektivy razvitiya na lokal'nyh territoriyah", RIOBarGU Press (in Russian).

Do gumannogo i socialnogo bachennya turizmu: Monreal's'ka deklaraciya. (1996). Available from: http://tourlib.net/books_ukr/filotur16.htm / (in Ukrianian)

Grigoryeva, V. (2008). Ekologicheski bezopasnyj turizm (ekoturizm, ekologicheskij turizm). Discover Baikal: otkroj Bajkal! Available from: http://www.discoverbaikal.ru/node/77 (in Russian).

Italiya - rodina agroturizma. (2019). Arenda v Italii. Available from: https://www.datscha-booking.com/183/europa/italiia/1.html (in Ukrianian)

Klikunova, V. (2008). Zelenaya al'ternativa - sel'skij turizm. Portal Uchebno-metodicheskogo centra Minsel'hozproda Respubliki Belarus. Available from: http://agroedu.of.by/index.php?option=com_content\&task=view\&id=152/ (in Russian)

Na Harkivshchini rozvivayut' sil's'kij zelenij turizm: vidznacheno vlasnikiv najkrashchih agrosadib. (2019). Harkivs'ka oblasna rada. Available from: http://www.oblrada.kharkov.ua/ua/press-center/news/16835-na-kharkivshchini-rozvivayut-silskij-zelenij-turizmvidznacheno-vlasnikiv-najkrashchikh-agrosadib/ (in Ukrianian)

Nikitina, O.A., Kushnarenko, E.P. (2010). Utochnenie ponyatijnogo apparata v razvitii teorii i praktiki regionalnogo selskogo turizma. Vestnik Chuvashskogo universiteta, 400-405 (in Russian).

Oppeld, L.I., Gordiyan, A.O., (2014). Mizhnarodnij dosvid zelenogo turizmu v Ukraïni : problemi ta perspektivi. Efektivna ekonomika, 1. Available from: http://www.economy.nayka.com.ua/?op=1\&z=2667/ (in Ukrianian)

Pecheritsa, E.V., Shevchenko, M.I. (2012). Mirovoj opyt agroturizma. Nacional'nye interesy: prioritety i bezopasnost, 41(182), 44-53 (in Russian).

Rozvitok silskogo zelenogo turizmu v Ukraïni ta Yevropi. (2019). Available from: http://tourlib.net/statti_ukr/parubok.htm/ (in Ukrianian)

Selskiy turizm v Indii: blizhe k istokam. (2019a). Available from: http://tourlib.net/statti_tourism/rural-tourism-india.htm/ (in Russian)

Selskiy turizm v Ispanii. (2019b). Available from: https://espanarusa.com/ru/pedia/article/77332/ (in Ukrianian)

Shvedun, V.O., Streltsov, V., Husarov, K.O., Sysoieva, S.I., Sheludko, R.M., Stankevych, S.V., Butenko, T.A., T.G. Tkachenko A.O. Khmyrova. (2019). The ukrainian market of ecological tourism: the current trends and development. Ukrainian Journal of Ecology, 9(4), 598-605.

Spilka spriyannya rozvitku silskogo zelenogo turizmu v Ukraïni. (2019a). Available from: https://www.greentour.com.ua/en/istoriya/ (in Ukrianian)

Spilka spriyannya rozvitku silskogo zelenogo turizmu v Ukraïni. (2019b). Available from: https://www.greentour.com.ua/en/history/ (in Ukrianian)

Stolyarchuk, P., Dominyuk, V. (2010). Analiz evropejs'kogo dosvidu organizaciï sil's'kogo zelenogo turizmu ta jogo kategorizaciï. Vimiryuval'na tekhnika ta metrologiya, 71, 175-184 (in Ukrianian).

World Wide Fund for Nature. (2019). Available from: http://wwf.ua/about_wwf/

Yatsenko, K.O. (2019). Rozvitok ob'ektiv zelenogo turizmu na Poltavshchini. Available from: http://oblrada.pl.ua/uploads/Istud/2014/01.pdf (in Ukrianian)

Yevropejskij dosvid organizaciï silskogo zelenogo turizmu. (2019). Available from: http://tourlib.net/statti_ukr/siltur2.htm/ (in Ukrianian)

Zaytseva, V.M. (2013). Svitovi tendenciï rozvitku silskogo ta agroturizmu. Ekonomika. Upravlinnya. Innovaciï, 2(10). Available from: http://nbuv.gov.ua/UJRN/eui_2013_2_28/ (in Ukrianian)

\section{Citation:}

Ulyanchenko O.V., Borysova O.V., Akhmedova O.O., Sysoieva S.I., Sheludko R.M., Stankevych S.V., Kovalova T.V., Khalmuradov B.D., Kharlamova Yu.Ye. (2019). Prospective use of ecological tourism in Ukraine and integrative view of international experience.

Ukrainian Journal of Ecology, 10(1), 49-54.

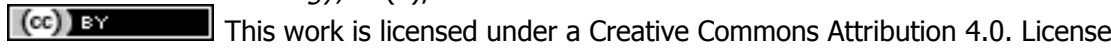

